Western University Scholarship@Western

2000

\title{
Talisman Energy, Sudan, and Corporate Social Responsibility
}

Chios Carmody

The University of Western Ontario

Follow this and additional works at: https://ir.lib.uwo.ca/lawpub

Part of the Human Rights Law Commons, Law and Economics Commons, Military, War, and Peace Commons, National Security Law Commons, and the Oil, Gas, and Mineral Law Commons

Citation of this paper:

Chi Carmody, "Talisman Energy, Sudan, and Corporate Social Responsibility" (2000) 38 Can YB Intl Law 237. 


\title{
Talisman Energy, Sudan, and Corporate Social Responsibility
}

\author{
by Chi Carmody ${ }^{1}$
}

\author{
I. Introduction \\ II. Talisman Energy and the Harker Report \\ III. Corporate Social Responsibility in Domestic and International Law \\ IV. The International Code of Ethics for Canadian Business \\ V. Talisman Energy's Corporate Social Responsibility Report 2000 \\ VI. Conclusion
}

\section{Introduction}

Sudan is a big country. It covers some 2.5-million square kilometers, or the size of Ontario and Québec combined. It is ethnically rich but developmentally poor: in 2001 it stood $138^{\text {th }}$ in the U.N. Development Program's Human Development Index, a broad measure of attainments in life expectancy, education and real income.

For all but 12 years since its independence in 1956 Sudan has been marked by a low-intensity civil war between the largely Arab and Muslim northern half of the country and the largely Black and Christian/animist south. The conflict involves an array of ethnic groups and has roots going back several centuries. ${ }^{2}$ In recent times the conflict has had devastating repercussions on the civilian population. The United Nations estimates that two million people have died in the fighting since 1983 and at least four million more are internally displaced. ${ }^{3}$ There have been reports of serious human rights violations by all sides, including abduction, slavery, forced displacement, starvation and murder. In 1999 the U.N. Rapporteur on Human Rights in Sudan termed the plight of civilians caught in the conflict "one of the most important human rights concerns facing the international community."

The civil war entered a new, and particularly vicious, phase in the late 1990s with the discovery of commercially viable quantities of oil in the south. The Sudanese government granted concessions for exploitation of the fields to foreign oil companies and sponsored the construction of a 1540-kilometre pipeline from southern oil fields to Port Sudan, a site on the Red Sea, to get the oil to market. The Chinese-built pipeline was one of the largest civil works projects in Sudanese history and represented a considerable

\footnotetext{
${ }^{1}$ Assistant Professor, Faculty of Law, University of Western Ontario, London, Ontario. The author would like to thank Amy Jacob for her assistance in locating tabular information for this comment.

${ }^{2}$ For background to the conflict see generally P.M. Holt \& W.M. Daly, A History of the Sudan: from the coming of Islam to the present day ( $5^{\text {th }}$ ed.) (2000); P. Woodward, Sudan, 1898-1989: the unstable state (1990).

3 U.N. Economic and Social Council, The Situation of Human Rights in the Sudan, E/CN.4/1999/38/Add.1, para. 42 (1999).

${ }^{4}$ Ibid., para. 159.
} 
achievement when oil began flowing in 1999. Sudan, which previously had to spend foreign exchange on its oil import bill, suddenly attained a degree of energy selfsufficiency and started to make money from oil exports. In the period 1998-2000 inflows of oil money went from being negligible to contributing $28.4 \%$ of government revenue. ${ }^{5}$ The money represented an opportunity to increase development spending, but at least some of it has gone towards military purchases. ${ }^{6}$ This has given a new edge to government forces. In January 2001 the U.N. Rapporteur indicated that "[o]il exploitation has resulted in the exacerbation of the war."7

The Khartoum government's principal opponent in the war is the Sudan People's Liberation Army (SPLA), which sees oil exploitation as enhancing the government's ability to fight. ${ }^{8}$ In 1994 the government and southern opposition groups concluded a Declaration of Principles, the cornerstone of which was official recognition of the right of self-determination for the people of southern Sudan. In 1995, however, the government chose to pursue a strategy of "peace from within" and in April 1997 signed the Khartoum Peace Agreement with six splinter rebel groups in which it emphasized that the general principles of the Declaration would guide future talks. Nevertheless, the SPLA refused to sign the Agreement because the government declared that it did not consider the Declaration to be binding, but merely a basis for future discussions. As a result hostilities continue.

Plans for an oil pipeline from the south were first made by Chevron, an American oil company, which began exploration in 1975. In 1984 the company halted its Sudan operation in response to the abduction and killing of three expatriate Chevron workers by the SPLA. Chevron eventually pulled out of Sudan altogether and sold its Sudanese assets to a small Canadian oil company which was acquired by Talisman Energy Inc. of Calgary in October 1998. As part of the purchase Talisman took over a 49,200-sq. km. concession 700 kilometres south of Khartoum. Talisman decided to operate the concession with the help of Chinese, Malaysian and Sudanese partners through a Mauritius-registered joint venture, Greater Nile Petroleum Operating Company (GNPOC), in which it retains a 25 percent interest. ${ }^{9}$ In 2000 Talisman provided the

${ }^{5}$ International Monetary Fund, Sudan: Staff Report for the 2000 Article IV Consultation and Fourth Review of the First Annual Program Under the Medium-Term Staff-Monitored Program, IMF Country Report No. 00/70 (June 2000) at p. 21.

${ }^{6}$ IMF staff observe that military expenditures increased by $35 \%$ in the 2000 program compared with 1999 and have "encouraged the authorities to keep it below budgeted levels" but note that "pressures for increased expenditures in this area are not likely to abate in the near future." Ibid., at p. 24,35 .

${ }^{7}$ U.N. Economic and Social Council, The Situation of Human Rights in the Sudan: Note by the Secretariat, E/CN.4/2001/48, para. 21 (Jan. 25, 2001).

${ }^{8}$ Amnesty International, Sudan: the Human Price of Oil, AFR 54/01/2000, p. 2 (May 2000).

${ }^{9}$ Other partners in the GNPOC consortium are a wholly owned subsidiary of the China National Petroleum Corporation (40\%), a wholly owned subsidiary of the national oil company of Malaysia, Petronas (30\%), and the national petroleum company of Sudan, Sudapet (5\%). Key management positions are occupied by representatives of each members of the consortium. 
government of Sudan with \$306-million worth in royalties from its share in GNPOC and reported a \$126-million profit on Sudan operations. ${ }^{10}$

Fig. 1

GNPOC Concession and Route of Oil Pipeline in Sudan

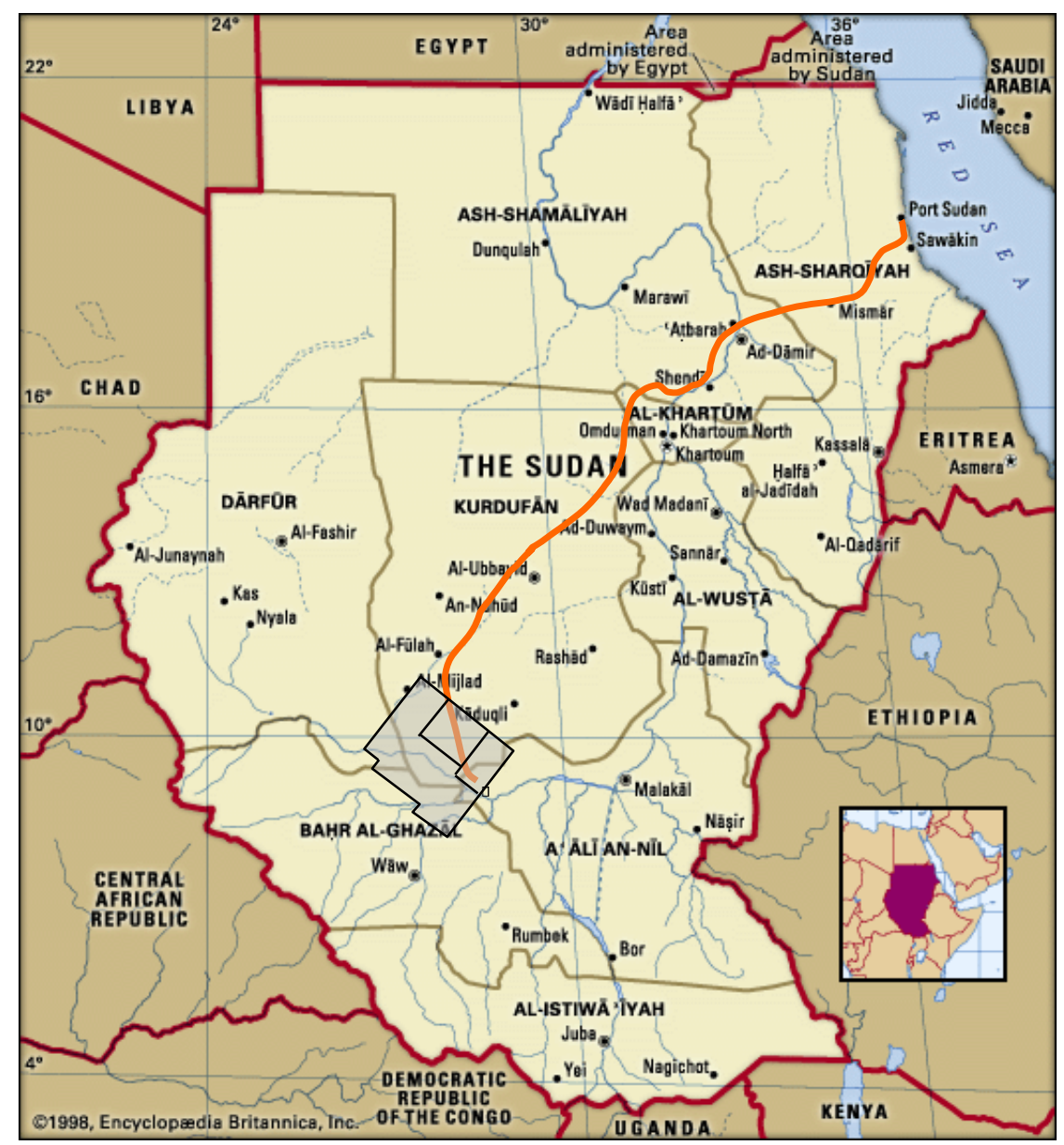

The GNPOC concession sits in the heart of disputed territory. Southern rebel groups have threatened that those working with the consortium will be regarded as, in effect, "northern" accomplices. ${ }^{11}$ Talisman therefore requested the Sudanese government to ensure law and order in the concession. ${ }^{12}$ To meet this request the government has

Decisions made by committees within GNPOC require an affirmative vote of two members of the board representing at least $60 \%$ interest.

${ }^{10}$ See Talisman Energy Social Responsibility Report 2000, p. 28 and Talisman Energy Annual Report 2000, p. 59.

${ }^{11}$ In its Corporate Social Responsibility Report 2000 Talisman notes that "periodic threats are made by rebel forces and clearly indicate that both [GNPOC] personnel and property are considered legitimate targets in the war against the Government of Sudan." See p. 14.

${ }^{12}$ Amnesty International, Sudan: the Human Price of Oil, AFR 54/01/2000, p. 8 (May 2000). 
employed the military and government-armed militias. There is, however, considerable evidence that the government has been using concession facilities to launch offensive operations within the concession and further south. ${ }^{13}$

Talisman's investment in Sudan therefore raises profound concern about corporate operations in countries where there are serious and frequent human rights violations. The company's presence has been interpreted by many as providing essential support to a repressive regime and as condoning the government's policies towards the south. This leads to the question what, if any, are Talisman's obligations at this particular juncture, one of fertile development in the field of international corporate social responsibility? This comment examines this question in light of recent events.

\section{Talisman Energy and the Harker Report}

Talisman has been the subject of scrutiny and criticism from church groups and other NGOs since the outset of its involvement in Sudan. These groups allege that GNPOC operations are aiding and abetting aggression against the civilian population. The principal criticisms made against Talisman can be grouped in three categories. The first concerns discriminatory hiring and forcible displacement of population in the concession area and along the pipeline route. The second involves the utilization of GNPOC-built facilities by Sudanese government forces for offensive military purposes. The third centers around the use of GNPOC-generated oil revenue by the Sudanese government for prosecution of the war.

In October 1999 growing criticism led the Canadian government to announce that it would send an envoy, former ILO representative John Harker, to Sudan to conduct an assessment mission of Talisman's operations. The inquiry was premised on the idea that there was a link between oil exploitation and human rights abuses, particularly slavery and slave-like practices, and that Canada was, in some sense, internationally responsible for the acts of its corporate "citizen", Talisman Energy. Harker's report concluded that GNPOC installations had been used to commit human rights violations, "that Sudan is a place of extraordinary suffering ... and [that] the oil operations in which a Canadian company is involved add more suffering." 14

The Canadian government did not respond in any legal way to Harker's

13 In its Corporate Social Responsibility Report 2000 Talisman notes that "Despite the Company's stated position regarding the use of the Heglig airstrip and advocacy efforts in this regard, we believe that there were at least four instances of non-defensive usage of the Heglig airstrip in 2000. On these occasions helicopters or planes landed on the airstrip for reasons that we could not determine were related to oilfield security and their presence was considered nondefensive by Talisman." (p. 16). See also J. Sallot, "Ottawa covering up for Talisman in Sudan, MP says", The Globe and Mail A5 (May 5, 2001).

${ }^{14}$ J. Harker, Human Security in Sudan: The Report of a Canadian Assessment Mission (January 2000) at p. 15. 
conclusions. ${ }^{15}$ Instead, it requested Talisman to abide by the International Code of Ethics for Canadian Business, a voluntary code of corporate conduct designed to be monitored by neutral third parties. ${ }^{16}$ The Canadian government also instituted a policy of engagement with the Sudanese regime, opening a consular office in Khartoum and holding talks with Sudanese officials on the human rights situation in the country.

Talisman adopted the Code in December 1999. Despite this action the company continues to be dodged by criticism and threats of shareholder divestment. In February 2000 the United States announced sanctions against GNPOC and in May 2000 a group of shareholders asked Talisman's Board of Directors to prepare an independently verified report on the company's compliance with the Code within 180 days. Talisman subsequently released its first Corporate Social Responsibility (CSR) Report under the Code in April 2001. ${ }^{17}$

\section{Corporate Social Responsibility in Domestic and International Law}

A corporation is a legal entity distinct from its shareholders with separate liability and the capacity of continuous succession. ${ }^{18}$ Although it is not unknown in international law, the corporation is principally a creation of domestic law and generally organized according to the laws of one jurisdiction. ${ }^{19}$ The typical corporation's business and affairs are managed by the board of directors who owe a duty to the corporation's collective ownership, the shareholders. Traditionally this duty was thought of as being to protect the corporation's capital and produce profits.

In the $20^{\text {th }}$ century duties owed by directors in law began to expand to employees, consumers and the general public. Recent literature on corporate governance refers to the "stakeholder" concept of the corporation, or the idea that the conduct of the corporation's

15 The Harker Report suggested that the Canadian government adopt a step-by-step approach to the situation, with a public statement expressing grave concern by the Minister of Foreign Affairs followed by an announcement that certain exports to Sudan would be subjected to scrutiny under the Export and Import Controls Act, R.S.C. 1985, ch. E-19, followed, if necessary, by placement of Sudan on the Area Control List. Harker also identified application of the Special Economic Measures Act, S.C. 1992 , c. 17 as a possibility.

16 The text of the Code is available at www.uottawa.ca/hrrec/busethics/codeint.html. For background see S. Chase, "Talisman Bows to Ottawa, adopts business code of ethics" The Globe and Mail, A1 (Dec. 11, 1999).

${ }^{17}$ Talisman Corporate Social Responsibility Report 2000, available at www.talisman-energy.com.

18 The Dictionary of Canadian Law ( $2^{\text {nd }}$ ed.) 260 (1995). For discussion in the international context see Barcelona Traction, Light and Power Co. (Belgium v. Spain), [1970] I.C.J. Rep. 3.

${ }^{19}$ Brownlie refers to the situation of intergovernmental corporations of private law whereby "states may by treaty create legal persons the status of which is regulated by the national law of one or more of the parties" and gives the example Eurofima, a company set up by 14 European countries under Swiss law in 1955 to jointly manage railway rolling stock. Even in this instance, however, there was reference to a governing system of domestic law. See I. Brownlie, Principles of Public International Law (5 ${ }^{\text {th }}$ ed.) 67 (1998). 
business affects not only shareholders but other sectors of the public as well. There is the increasingly current view that these other interests should be accounted in some way.

Apart from specific statutory obligations, however, courts in Canada and elsewhere have in general been reluctant to accept the idea that corporate directors owe a duty to the general public or to any particular sector thereof. ${ }^{20}$ Instead, changes taking place in corporate governance are being self- or statutorily imposed. For instance, many mutual funds already keep a close watch on how firms deal with a variety of controversies. This growing interest is also reflected in amendments to legislation in countries like Britain, where new rules require pension funds to disclose how they deal with outside issues. ${ }^{21}$

International law does not yet have much to say formally about corporate social responsibility. The language of the Universal Declaration of Human Rights ${ }^{22}$, which speaks of "every individual and every organ of society" as having a duty to strive for the promotion of human rights, is sometimes referred to as evidence that corporations, as legal persons, have such a duty. Certain instruments, such as the ILO Tripartite Declaration of Principles Concerning Multinational Enterprises and Social Policy ${ }^{23}$, the OECD Guidelines for Multinational Enterprises ${ }^{24}$ and the U.N. Draft International Code of Conduct on Transnational Corporations ${ }^{25}$, could be considered a framework for international corporate behavior, but none has been consistently endorsed in terms of adherence or practice by a clear majority of the international community. There remains, in addition, the question of how to regulate private entities in a system of public law. Moreover most instruments have been drafted by existing states and, in deference to sensitivities of sovereignty, focus more on individual human rights than on group rights to self-determination now at the heart of the conflict in Sudan. For instance the Tripartite Declaration provides that:

20 "The firmly established rule at common law was that directors owe a fiduciary obligation to the corporation, but not to individual shareholders. The current view would appear to be that, while special circumstances may give rise to a fiduciary relationship between a director and shareholders, no general fiduciary obligation exists." McCarthy Tétrault, Directors and Officers Duties and Liabilities in Canada $42-43$ (1997); see Bell v. Source Data Control Ltd., (1988) 66 O.R. (2d) 78 (C.A.); Brant Investments Ltd. v. KeepRite Inc. (1987), 60 O.R. (2d) 737 (H.C.), aff'd (1991), 3 O.R. (3d) 289 (C.A.). In England see Howard Smith Ltd. v. Ampol Petroleum, [1974] A.C. 821 (P.C.); in the United States see Revlon Inc. v. MacAndrews \& Forbes Holdings, Inc., 506 A.2d 173 (Del. 1986).

${ }^{21}$ In July 2000 the British government introduced a Socially Responsible Investment regulation under s. 35 of the Pensions Act 1995 which requires pension funds to disclose the extent to which they consider social, environmental or other ethical criteria in investment decisions, and policies directing the exercise of rights (e.g. voting) attached to their investments.

${ }^{22}$ G.A. Res. 217 A (III), U.N. Doc. A/810 at 71 (1948).

${ }^{23} 17$ I.L.M. 422 (1978).

${ }^{24} 15$ I.L.M. 969 (1976).

2523 I.L.M. 626 (1984). 
All parties concerned by this Declaration should respect the sovereign rights of States, obey the national laws and regulations, give due consideration to local practices and respect relevant international standards. They should respect the Universal Declaration of Human Rights and the corresponding International Covenants adopted by the General Assembly of the United Nations as well as the Constitution of the International Labour Organisation and its principles .... They should also honour commitments which they have freely entered into, in conformity with the national law and accepted international obligations. ${ }^{26}$

These human rights are important, but they alone are not a useful measure of Talisman's activities in the current context. Some accounting of Talisman's activities in relation to group rights is necessary.

Recently, the position of international law regarding corporate social responsibility has begun to change. This is happening for two reasons. First, there has been tremendous development of soft law codes of conduct, a development prompted in part by the lack of anything similar at an official level. Initiatives such as the Amnesty International Guidelines for Companies ${ }^{27}$, Social Accountability $8000^{28}$, the U.N. Global Compact $^{29}$, the Taskforce on the Churches and Corporate Responsibility Benchmarks for Measuring Business Performance ${ }^{30}$ and the Global Sullivan Principles $^{31}$ have proliferated. These seem to appeal to the free-market tenor of the times in being nongovernmental and self-regulating.

\footnotetext{
26 17 I.L.M. 422 at 424 (1978).

${ }^{27}$ Available at www.amnesty.org.uk/business/pubs.

${ }^{28}$ Social Accountability 8000 is a standards association established in 1997 to verify international labour conditions in a transparent manner and is modeled on the international standards organization ISO 9000 standard used by companies for quality control purposes. See www.cepaa.org/introduction.htm.

${ }^{29}$ U.N. Secretary-General Kofi Annan first proposed the Global Compact in an address to the World Economic Forum in January 1999. He challenged world business leaders to help build the social and environmental pillars required to sustain the new global economy. The Compact encompasses nine principles drawn from the Universal Declaration of Human Rights, the ILO's Fundamental Principles on Rights at Work and the Rio Principles on Environment and Development. The Compact promotes good practices by corporations. It does not endorse companies. See www.unglobalcompact.org.

30 The Taskforce on the Churches and Corporate Responsibility (TCCR) is an ecumenical coalition of major churches in Canada. It assists member organizations in promoting and implementing policies adopted by them on the social and environmental responsibility of Canadian-based corporations and financial institutions: www.web.net/ tccr/

31 The Global Sullivan Principles (GSP) derive from the original Sullivan Principles, a code of conduct for companies operating in South Africa devised by a Philadelphia cleric, the Rev. Leon Sullivan, in 1977. In 1997 they were updated and renamed the GSP. See globalsullivanprinciples.org
} 
Second, the foregoing private initiatives, together with renewed concern about international corporate power and business ethics, are promoting something of a renaissance in multilateral efforts to define corporate social responsibility. Thus, new voluntary instruments have either been adopted or are under consideration by the U.N. ${ }^{32}$, $\mathrm{OECD}^{33}$ and $\mathrm{EU}^{34}$.

One multilateral initiative meriting particular attention is the United Nations Draft Human Rights Guidelines for Companies ${ }^{35}$. The Draft Human Rights Guidelines were begun in 1999 in response to concern about the unwieldly proliferation of soft law. Simply put, the fear was that the multiplicity of mechanisms was allowing companies to pick and choose or to claim that the range of choices inhibited them from acting. The Guidelines thus seek to comprehensively interpret the Universal Declaration in a form which can be implemented by private entities. The Guidelines are more precise and nuanced than the Universal Declaration, and therefore better at covering the variety of circumstances in which human rights need protection. For example Draft Art. 16 states that:

Companies shall have the responsibility to ensure that their business operations do not contribute directly or indirectly to human rights abuses and actively to speak out or otherwise use their influence in order to help promote and ensure respect for human rights.

The reference here regarding indirect corporate contribution to human rights abuses is particularly noteworthy. Likewise, Draft Art. 18 states that:

Companies shall respect the rights of indigenous communities and minorities to own, develop, control, protect, and use their lands and cultural and intellectual property; indigenous communities and minorities may not be deprived of their own means of subsistence.

This last provision presents something of an advance over the statist position of previous documents. Properly implemented, it could sanction the kind of activity Talisman now finds itself undertaking in southern Sudan. However the Draft Guidelines remain both a

${ }^{32}$ The U.N. Commission on Human Rights Sub-Commission on the Promotion and Protection of Human Rights is currently working on a set of Draft Universal Human Rights Guidelines for Companies. See E/CN.4/Sub.2/2001/WG.2/WP.1/Add.1 (2001).

33 Guidelines for Multinational Enterprises, 40 I.L.M. 237 (2001). The Guidelines are recommendations made by OECD member governments to multinational enterprises and address a range of corporate activity that have become of pressing concerning since the last set of general OECD Guidelines issued in 1976.

${ }^{34}$ In January 1999 the European Parliament adopted a set of proposals on the accountability of European-based multinationals. The proposals, derived from a report entitled Towards a European Code of Conduct, aim to establish a "European Monitoring Platform" concerning multinational accountability on a broad range of social issues.

${ }^{35}$ U.N. Commission on Human Rights, E/CN.4/Sub.2/2000/WG.2/WP.1/Add.1 (May 25, 2000). 
"draft" and "guidelines", with all the limited normative significance that those terms entail. The long-term hope is that they will one day become a binding framework for companies, but at present they are not.

In the meantime it is possible to conclude that Talisman, in continuing to operate in Sudan with clear evidence that oil revenues are financing the civil war, is indirectly contributing to serious human rights abuses. In this respect it is in breach of the Draft Guidelines and, by extension, the Universal Declaration. A second conclusion is that Talisman is operating in the south with permission of the government. Given the state of civil war in the country, however, that permission cannot be said to reflect the will of southerners. As a minority they are entitled to a degree of control over resources emanating from their lands. This is confirmed by a number of new instruments. ${ }^{36}$ It is also rapidly becoming a norm of state practice. Talisman is therefore in breach of the Draft Guidelines and of an emerging norm of international law in appropriating resources without consent.

\section{The International Code of Ethics for Canadian Business}

A Canadian attempt to deal with issues of corporate social responsibility occurred in 1997 when a roundtable of corporate, NGO and academic representatives created an International Code of Ethics for Canadian Business. This followed a public outcry over Canadian corporate activity in the Nigerian petroleum industry under the Abacha dictatorship. The Code is a collection of beliefs, values and principles guided by an overall vision of Canadian business abroad as both profitable and socially responsible. The Code was adopted by 13 companies at the time of its creation. The most recent information available indicates that only two Canadian companies, including Talisman, have signed on since. The Code is voluntary and non-binding and in this sense does not add much to the instruments already reviewed, but because Talisman's efforts in corporate responsibility are measured according it, the Code should be examined.

The Code reflects five generations of corporate conduct, with the first (conflict of interest) bearing primarily on corporate interest while the remaining four (commercial conduct, employee and other third party concerns, community and environmental concerns, and accountability and social justice) refer to external interests and values. The Code expresses the belief that "businesses should take a leadership role through establishment of ethical business principles", and that while "confrontation should be tempered by diplomacy" and "national governments have the prerogative to conduct their own government and legal affairs in accordance with their sovereign rights", "all governments should comply with international treaties and other agreements that they have committed to". The Code also enshrines principles that companies will "support and promote the protection of international human rights within our sphere of influence" and "not be complicit in human rights abuses". Similarly they will "comply with all

\footnotetext{
${ }^{36}$ See Convention concerning Indigenous and Tribal Peoples in Independent Countries, ILO Convention No. 169, 28 I.L.M. 1382 (1989); Convention on Biological Diversity, 31 I.L.M. 818 (1992); Draft Universal Declaration on Indigenous Rights, 34 I.L.M. 541 (1995).
} 
applicable laws" and will "strive for social justice and promote freedom of expression in the workplace."

The Code is to be implemented in individual firms through the development of operational codes and practices. There is no guide as to how this translation is to be effected, except that the result must be "consistent" with the Code's provisions. Verification is to be effected by outside parties hired by signatories to the Code for that purpose.

\section{Talisman Energy's Corporate Social Responsibility Report 2000}

Talisman's Corporate Social Responsibility (CSR) Report 2000 was released in April 2001 in an effort to comply with the Code. The 42-page Report was verified by PricewaterhouseCoopers (PwC), a worldwide consulting firm, and provides a snapshot of Talisman and its operations in Sudan. Unlike audited accounting reports, the Report is self-admittedly not "a broad overall assessment of our presence in Sudan. Rather, it describes how we have interpreted the Code through the Principles which we have adopted." 37 Talisman notes that there are no generally accepted standards against which its activities can be measured. Consequently, it plans to spend the period 2001-2003 developing performance indicators. With these, presumably, Talisman will be in a better position to be assessed. The CSR Report observes "we intend to expand the reporting process in future years." 38

The prototypical nature of the CSR Report is underlined in PwC's Verification Statement, which observes that "There are currently no statutory requirements or generally accepted international standards for the preparation, public reporting and attestation or corporate social responsibility reports." For this reason PwC's verification approach "reflects emerging best practice and is in accordance with the International Standard on Assurance Engagements." 39 The Verification Statement also notes significant limitations on PwC's work. Certain visits had to be cleared with GNPOC or national security, who have a record of antipathy towards southerners and who might make access to southern representatives difficult. Likewise the Statement indicates that PwC auditors "did not visit any sites in the south of Sudan outside the concession area but we did speak to Southern Sudanese in Khartoum and to international nongovernmental organisations in Nairobi." 40 Thus it is not entirely clear how or where inside Sudan PwC consulted with independent southern sources.

The CSR Report goes on to define corporate social responsibility as "conducting activities in an economically, socially and environmentally responsible manner."41

\footnotetext{
${ }^{37}$ CSR Report, p. 9.

${ }^{38}$ CSR Report, p. 41.

${ }^{39}$ CSR Report, p. 11.

${ }^{40}$ CSR Report, p. 11.

${ }^{41}$ CSR Report, p. 4.
} 
Responsibility is, in turn, conceived of according to the International Code of Ethics for Canadian Business, a translation of the Code for GNPOC purposes (the Sudan Operating Principles), and key stakeholder concerns. From these are derived concrete aims in the form of Talisman objectives ("those which are under our direct control and responsibility"), GNPOC objectives ("those objectives whose achievement depends on the agreement or support of our GNPOC business partners") and advocacy objectives ("those over which we have minimal control but for which we believe we have a responsibility to advocate within governments or international organizations").

The CSR Report is divided into several sections. Objectives are considered in chapters on human rights, community participation, employee rights, ethical business conduct, health safety and the environment, and stakeholder engagement. Thus, for instance, the International Code's principle of support for human rights is translated into a commitment to uphold the Universal Declaration of Human Rights under the Sudan Operating Principles, followed by an accounting for key stakeholder concerns, and several specific objectives. An overview of this translation is provided in Fig. 2. 
Fig. 2

Talisman's Formulation of Corporate Responsibility Objectives in the Field of Human Rights

\begin{tabular}{|c|c|c|c|c|c|}
\hline $\begin{array}{l}\text { The International } \\
\text { Code of Ethics for } \\
\text { Canadian Business }\end{array}$ & $\begin{array}{l}\text { Sudan Operating } \\
\text { Principles }\end{array}$ & $\begin{array}{l}\text { Key Stakeholder } \\
\text { Concerns }\end{array}$ & $\begin{array}{l}\text { Talisman } \\
\text { Objectives }\end{array}$ & $\begin{array}{c}\text { GNPOC } \\
\text { Objectives }\end{array}$ & $\begin{array}{c}\text { General Advocacy } \\
\text { Objectives }\end{array}$ \\
\hline $\begin{array}{l}\text { Support and promote the ... } \\
\text { protection of international } \\
\text { human rights within sphere } \\
\text { of influence. } \\
\text { Not to be complicit in } \\
\text { human rights abuses. }\end{array}$ & $\begin{array}{l}\text { Commitment to upholding } \\
\text { the Universal Declaration } \\
\text { of Human Rights. } \\
\text { Commitment to addressing } \\
\text { human rights concerns } \\
\text { arising from our own and } \\
\text { GNPOC operations. }\end{array}$ & 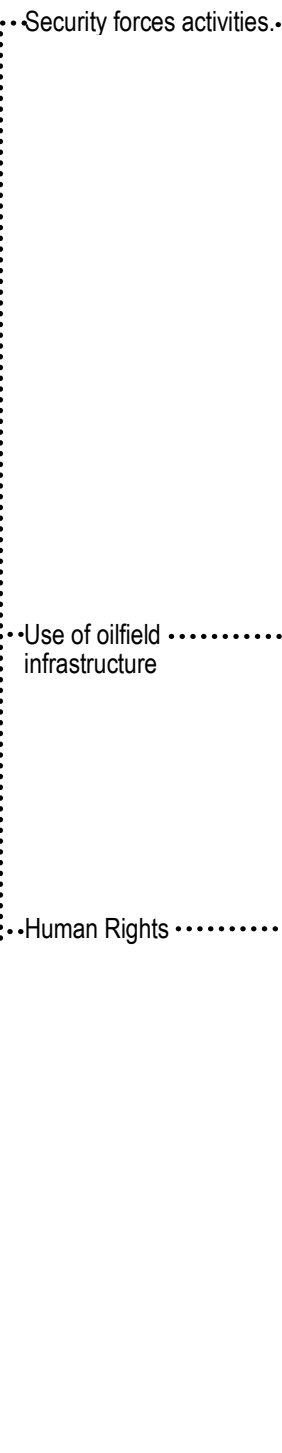 & 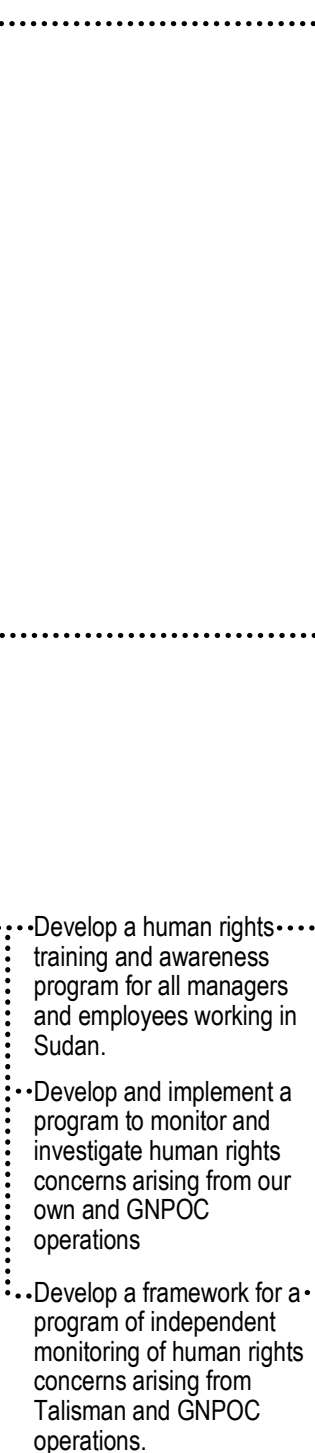 & $\begin{array}{l}\text {..Promote to GNPOC ....... } \\
\text { partners the formalization } \\
\text { of the provision of security } \\
\text { that complies with the } \\
\text { pertinent UN Codes of } \\
\text { Conduct. } \\
\vdots . \text {. Use corporate influence to } \\
\text { ensure that the GNPOC } \\
\text { infrastructure is not used } \\
\text { for offensive military } \\
\text { purposes. } \\
\vdots . \text {. Work with GNPOC } \\
\text { partners to provide training } \\
\text { to GNPOC security } \\
\text { personnel on human rights } \\
\text { and international standards } \\
\text { for use of security and } \\
\text { forces. } \\
\\
\ldots \text {. Promote to GNPOC ....... } \\
\text { partners the development } \\
\text { of guidelines on the } \\
\text { acceptable uses of oilfield } \\
\text { infrastructure and promote } \\
\text { the implementation of this } \\
\text { program to our GNPOC } \\
\text { partners. } \\
\end{array}$ & $\begin{array}{l}\text { Promote to the } \\
\text { Government of Sudan the } \\
\text { development of guidelines } \\
\text { on the acceptable uses of } \\
\text { oilfield infrastructure. }\end{array}$ \\
\hline
\end{tabular}

The translation of principles and concerns into objectives is generally worthwhile. Where problems arise, they are often with the appropriateness of objectives in context. For instance, Talisman has translated the Code principle that it will "support and promote the protection of international human rights within our sphere of influence" into "we are committed to upholding the Universal Declaration of Human Rights." This formulation is questionable inasmuch as the Declaration itself is generally regarded as aspirational and has been refined in the International Covenant on Civil and Political Rights and the International Covenant on Economic, Social and Cultural Rights, both of which Sudan 
has ratified. ${ }^{42}$ These later instruments, together with such documents as the International Convention on the Elimination of All Forms of Racial Discrimination ${ }^{43}$, the ILO Convention on Discrimination (Employment and Occupation) ${ }^{44}$, the 1994 Declaration of Principles and the 1997 Khartoum Peace Agreement - which have been approved by the Sudanese government - would constitute a more specific and effective basis for Talisman's advocacy. Talisman counters that it can only be expected to advocate within its "sphere of influence", but this sphere should be broadly conceived by the company given its major role in the Sudanese economy and its record of influence with the Khartoum government. There is, moreover, no requirement that Talisman limit itself to lobbying on the basis of documents that apply to it. In this connection the company should recall the Code principle that "all governments should comply with international treaties and other agreements that they have committed to".

A second concern with objectives as detailed in the CSR Report is the failure of Talisman to account for, and seek the return of, civilians forcibly displaced from their homes in the concession area and along the pipeline route. The relevant international standard in this respect, the U.N. Guiding Principles on Internal Displacement, mandates that "[d]isplacement shall last no longer than required by the circumstances". ${ }^{45}$ The CSR Report takes a more restricted view of the appropriate GNPOC objective: it is to "promote the principle that people adversely impacted by GNPOC operations receive fair and just compensation". The Report details that during the planning and construction of the pipeline the government formed a Pipeline Compensation Committee and "through this process thousands of compensation cases have been paid". However, Talisman admits that "the process of identifying people affected by such activity and the provision of fair compensation has not been well documented." 46 It would seem that what is necessary is for Talisman to press GNPOC to conduct some accounting of the massive human displacement related to oil exploration, as detailed in the Harker Report and elsewhere, and to seek the return of people so displaced. Instead, the CSR Report speaks merely in terms of compensation, and in that respect, in sums that could not possibly reasonably compensate for the dislocation and hardship that have taken place.

The dissonance between Talisman and independent sources is repeated elsewhere. The CSR Report notes, for instance, that Talisman has developed "a detailed human rights monitoring and investigation program manual to address concerns arising from GNPOC operations" but the small number of complaints through it does not match thirdparty reports of atrocities or abuse, suggesting some other explanation for the company's results. Talisman notes, for instance:

42993 U.N.T.S. 3 (1976), 999 U.N.T.S. 171 (1976).

${ }^{43} 660$ U.N.T.S. 195 (1966).

44362 U.N.T.S. 31 (1958).

${ }^{45}$ Contained as an annex to the Report of the Representative of the Secretary-General, Mr. Francis M. Deng, U.N. Doc. E/CN.4/1998/53/Add.2 (Feb. 1998). See Principle 6(3).

${ }^{46}$ CSR Report, p. 17. 
Our records show that a further 10 cases were opened in November 2000 to keep files of initial interviews with people who have been displaced. These cases include six individuals who have come to Paryang during 2000 from surrounding villages to escape from famine, disease or conflict; and two people who left Paryang, seven and 20 years ago respectively, and have now returned. ${ }^{47}$

Contrast this with the testimony of a refugee - far from unique - about conditions in Paryang given to the Harker mission the year before and included in its Report:

About 200 people came to Biem from Paryang. I came from Paryang in May. My family was repatriated to Paryang from Khartoum by the Government of Sudan and the Government would not let us leave Paryang town. The Government of Sudan forces mistreated us. We were not given any services, we had to find our own food and make our own living. When the women would go to gather wood and cut grass to build shelters, the Arab militia followed is to take what we had and rape us. I tried to escape with three others from the town. The Government of Sudan [forces] shot at us. The others were killed. I was hit in the leg but managed to escape. ${ }^{48}$

A similar discrepancy exists in Talisman's version of military use of the Talisman-built Heglig airstrip, which the company describes in terms of there having been "at least four instances of non-defensive usage of the Heglig airstrip in 2000." The Harker Report, on the other hand, noted:

We also learned, and have reported, that flights clearly linked to the oil war have been a regular feature of life at the Heglig airstrip, which is adjacent to the oil workers' compound. It is operated by the consortium, and Canadian chartered helicopters and fixed wing aircraft which use the strip have shared the facilities with helicopter gunships and Antonov bombers of the Government of Sudan. These have armed and re-fuelled at Heglig and from there attacked civilians. ${ }^{49}$

Given details in the Harker Report and incidents raised by the U.N. Rapporteur and NGOs, one could have reasonably expected Talisman's auditors would make some effort to deal with them, yet there is nothing of the sort. For example, the murder of eight Nuer tribesmen who had gone seeking jobs with GNPOC in August 1999 and were put to death for it, according to the Harker Report, is nowhere addressed. ${ }^{50}$ In general there is an empty, dream-like quality to the CSR Report's descriptions and numbers which vary so considerably from reliable outside reports that they must be taken to greatly understate the magnitude of the situation. Simply put, the effort made by Talisman does not square

${ }^{47}$ CSR Report, p. 18.

${ }^{48}$ Harker Report, p. 84.

${ }^{49}$ Harker Report, p. 15.

${ }^{50}$ On this particular incident John Harker went so far as to express his hope in the Report that the Government of Canada "will call for an investigation of [this] serious allegation" and added that "[w]e hope Talisman will join us in calling for, and facilitating, the investigation we seek." Ibid., p. 14. 
with its obligation under the Code and in an emerging field of international law to "take a leadership role" in investigating and correcting human rights abuses caused by its activities.

Perhaps the most profound weakness of the CSR Report is its failure to address explicitly the question of the company's continuing presence in Sudan. This is an issue that looms large over Talisman's operation and before any reader of the Report. However, it receives almost no attention. Instead, the company sidesteps the question, adopting a sort of earnest "gee shucks - we're learning" tone and justifying its operation in the narrowest and most formal of terms, as the following passage demonstrates:

There is a legitimate debate regarding the role of development in areas of civil unrest. We believe that our involvement in Sudan is a positive one and that our actions are in compliance with the International Code of Ethics for Canadian Business. We also believe that we can help the people of Sudan by providing employment and skills training, enhancing local infrastructure, supporting further economic development, and by doing what we can to support peace and stability in the region. We recognize that others have differing opinions. ${ }^{51}$

Talisman's implicit position appears to be that "it's better for us to be doing this than someone else who might not be as committed to human rights as we are." The point is, however, that misery remains, and pumping oil by anyone exacerbates it. One might, of course, ask the question posed by a Sudanese academic and headlined in the Report: "If Talisman were to leave, would the oil stop flowing?", but this undermines the principle of the universality of human rights and has to be dismissed. Human rights are rights as well as obligations and are Talisman's to uphold regardless of what others do in its place. At the very least the company could have expressed a more considered rationale for its presence in Sudan. Without one, Talisman's commitment to corporate social responsibility in this context appears questionable.

There are some positive developments outlined in the CSR Report. Talisman indicates that it will use its influence to ensure GNPOC job candidates are treated equally and not discriminated against, a problem identified in the Harker Report. ${ }^{52}$ More generally the company is trying to instill a community of respect for human rights among its employees by sending Talisman employees to courses at the Pearson Peacekeeping Centre in Clementsport, Nova Scotia. Assistance of a material nature is also being provided through Talisman philanthropy. The CSR Report refers to Talisman-supplied medical services, waterworks, education and emergency relief worth $\$ 1$ million given in 2000. More money will be given in future. The CSR Report includes a profile of

\footnotetext{
${ }^{51}$ CSR Report, p. 42.

52 "Certainly, there seem to be few, if any, Nuer or Dinka at work at Heglig, which seems to fit a widely held view in Western Upper Nile that the [Government of Sudan], thus GNPOC, views all non-Arabs as potential threats to security. ... If Talisman was serious about being a good corporate citizen, it would win the support of its GNPOC partners to have an audit of hiring and employment practices carried out by the International Labour Organization." Harker Report, p. 14 (emphasis in original).
} 
GNPOC's national employee complex in Khartoum, although systemic bias in GNPOC hiring means few southerners are likely to benefit from it. It also highlights Talisman's assistance to a vocational school, again in Khartoum, which provides trades training to 1,000 boys. The CSR Report does not say, however, what Talisman is doing to improve vocational prospects for Sudanese women.

Talisman's efforts are noteworthy. At the same time, however, they must be understood in the context of what GNPOC is doing. Oil development is the indirect cause of serious human rights abuses in Sudan. Talisman and its partners appear to be trying to do something about them, but they have completely neglected the group rights that are at the root of these acts and an honest examination of their own contribution to the conflict. Many critical questions have been raised by others and could have been addressed here. In most respects they were not. Consequently, the CSR Report comes across as superficial and falls well short of evoking the robust spirit in which the Code was conceived.

\section{Conclusion}

Talisman Energy's CSR Report in southern Sudan presents a mixed, but ultimately disappointing, picture. On the one hand the company has committed itself to a leadership role in corporate social responsibility and has done some things to alleviate some individual human rights abuses. On the other hand, the company's actions to date appear insufficient. It has failed to adequately examine the most profound question, which is whether it should pull-out. There can be nothing but a sense of dissatisfaction at Talisman's failure to assess its Sudan operation critically.

What can be done? The situation here is complicated by the form in which Talisman operates in Sudan. GNPOC is Mauritius-registered and Khartoum-based. It has a part owner which is Canadian. Could Canada be held responsible for Talisman/GNPOC acts? International law does not provide a general rule on the attribution of responsibility for corporate activity. Some reference to broad principle is necessary.

The general rule of international law is to authorize the national state of a company to exercise a right of diplomatic protection on its behalf. At the same time several regimes and authorities of international law require a genuine link or connection between a company and a protecting state based on the nature and quality of the contacts in question. ${ }^{53}$ If a right of diplomatic protection is enjoyed, there is presumptively no reason why a duty of diplomatic responsibility should not arise. It makes sense that this duty should be proportional to the foreseeability and degree of corporate involvement, to the capacity to act, and to the nature and gravity of the wrong.

In this instance it is clear that Mauritius has no real connection with the situation

\footnotetext{
${ }^{53}$ C.F. Amerasinghe, "Jurisdiction Ratione Personae under the Convention on the Settlement of Investment Disputes Between States and Nationals of Other States" (1974-75) 47 Br. Y.B. Int'l L. 227 at 267.
} 
and that the national governments of Talisman's major co-partners, China and Malaysia, will not pursue the matter. Canada is left to deal with the abuses, which are serious and not entirely unforeseen. ${ }^{54}$ The government has asked Talisman to adhere to the Code and has undertaken a process of dialogue with the Sudanese government. In light of the Code's modest impact on Talisman's corporate conduct, however, what else can be done? The Harker Report referred to several options, including putting certain Sudanese goods on the Import Control List, putting Sudan itself on the Area Control List, or, in the case of multilateral sanctions against Sudan, invoking the Special Economic Measures Act. The difficulty with all of these options is that Canada-Sudan trade is negligible and that there is no enthusiasm for multilateral sanctions against Sudan. ${ }^{55}$ This leaves the government's current strategy of constructive engagement as the only practical prospect.

Another consideration is the United States. Sudan may be distant, but it has not gone unnoticed in Washington. The fact that Canadian and other foreign oil companies are profiting from their Sudanese ventures has increased American oil companies' interest in joining them. At present they are forbidden by U.S. sanctions from participating in operations in Sudan, but recent American diplomacy has indicated a desire to find a solution to the conflict. ${ }^{56}$ There are signs that Sudanese political figures have been receptive to this pressure. ${ }^{57}$

Could Canadian corporate behaviour be a catalyst for change abroad? That is clearly Talisman and the government's hope. Those who observe events in Sudan with history in mind will recall the "intermediate" period of Canadian corporate participation in South Africa in the 1970s after the Canadian government's prohibition on new investment but before the push for divestment. At that time like arguments were made about continuing the corporate presence of enlightened foreign employers under

\footnotetext{
54 "Canada has in the past expressed grave reservations concerning private sector involvement that may heighten tensions or otherwise fuel ongoing conflicts. Canada has consistently discouraged companies from doing business in Sudan and in 1992 suspended all support, including export finance and trade development programs. It has also issued warnings regarding therisks of working in the Sudanese oilfields due to security concerns and the potential danger to employees." Harker Report, p. 25.

${ }^{55}$ Article 4 of SEMA provides that the government may only invoke the Act "for the purpose of implementing a decision, resolution or recommendation of an international organization of states or association of states, of which Canada is a member, that calls on its members to take economic measures against a foreign state." Alternatively, measures may be taken where the government "is of the opinion that a grave breach of international peace and security has occurred that has resulted or is likely to result in a serious international crisis." The phrase "grave breach of international peace and security" is generally taken to mean Security Council action under Ch. VII of the U.N. Charter.

${ }^{56}$ M. Lacey, "Sudan War in Agenda for Powell in Africa Visit" The New York Times (May 23, 2001); J. Perlez, "Suddenly in Sudan, a Moment to Care" The New York Times (June 17, 2001).

57 J. Harker, "A Small Start on Peace" The Globe \& Mail (June 1, 2001) (referring to the commencement of negotiations between the Khartoum government and southern forces in Nairobi).
} 
apartheid.

It is hard, however, to make any such analogy here. The prevailing political constellation, the specificity of the actors involved, the rights at issue and the magnitude of abuse all call for a serious re-evaluation of Canadian corporate activity in Sudan. In this respect it should also be recalled that the intermediate period in apartheid-era South Africa was followed by widespread divestment. 